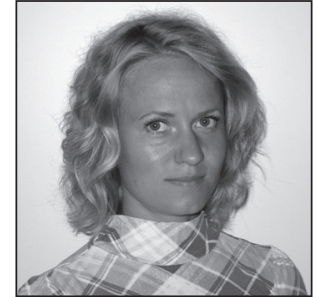

Tuuli Hansen

\title{
Case Law of the European Court of Human Rights and the Supreme Court of Estonia on Disclosing Personal Data in Court Judgements
}

\section{Introduction}

Increased interest of the public in the protection of personal data is manifested in the increasing number of applications to courts dealing with the rights of a data subject to contest further data processing and be forgotten. ${ }^{*}{ }^{1}$ The concept of personal data undoubtedly involves the name of a person in association with his or her procedural position and the details on his or her activities revealed in judgements. ${ }^{{ }^{2}}$

The object of the article is to compare the case law of the Administrative Law Chamber of the Supreme Court of Estonia (ALCSC) ${ }^{*} 3$ and the European Court of Human Rights (ECtHR) in publishing judgements on the merits of individual petitions in 2013 and $2014^{*} 4$ in Internet-based judgement databases. ${ }^{*} 5$ The objective is to find regularities in the protection of the applicants' personal data in the publishing of decisions.

The article examines the provisions regulating the disclosure of personal data in the judgements of the ECtHR and the ALCSC and analyses how parties to proceedings are informed of the possibilities for protecting their right to privacy. The case law analysis focuses on determining the fields in which anonymity is ensured for applicants by request of a party to a proceeding or at the court's initiative.

1 Internet: Case-Law of the European Court of Human Rights. Council of Europe; European Court of Human Rights 2011, p. 10. Available at http://www.echr.coe.int/Documents/Research_report_internet_ENG.pdf (most recently accessed on 8.8.2015).

2 Analogously, the Court of Justice has found that the concept of personal data undoubtedly covers the name of a person in conjunction with his telephone coordinates or information about his working conditions or hobbies. ECJ 6.11.2003, C-101/01, Bodil Lindqvist.

3 The author analyses the case law of the Administrative Law Chamber since the decisions of the Supreme Court and of the ECtHR are the most similar from the point of view of a party to a proceeding - a person has turned to court against the state in relation to violation of his or her rights or freedoms.

4 Decisions on cases declared admissible by the courts.

5 The author has also analysed the ECtHR's practice in applying anonymity over a shorter period in the earlier article T. Hansen. Euroopa Inimõiguste Kohtu praktika kohtuotsustes isikuandmete avaldamisel (Case Law of the European Court of Human Rights in Relation to the Disclosure of Personal Information). - Juridica 2014/4, pp. 313-324 (in Estonian). 


\section{Regulation of disclosure of personal data}

\subsection{Procedural law regulating the publication of judicial decisions}

From a wider perspective, both the European Convention for the Protection of Human Rights and Fundamental Freedoms ${ }^{* 6}$ (the ECHR, referred to also as 'the Convention') and the Constitution of the Republic of Estonia ${ }^{* 7}$ incorporate contrasting legal values of the openness of administration of justice and the personal right to privacy. This article focuses on the collision of public pronouncement of judgements with the principles enshrining the protection of personal data.

Section 24 of the Constitution of the Republic of Estonia and the Codes of Procedure establish that judicial proceedings and decisions are usually public and the enforced judgements shall be published online at the prescribed location.

According to Rules 33 and 78 of the Rules of Court, adopted under Article 25 of the ECHR, ${ }^{*}$ the documents and decisions submitted to the ECtHR are usually public and available in public databases. According to Article 35 (2) (a) of the ECHR, the ECtHR shall not deal with applications that are anonymous.

Applicants can request anonymity from the Court. From the aspect of data protection, it is assumed that in case of anonymous data, the person cannot be identified because all identifying elements have been removed from the dataset. Anonymity can also be defined as any information relating to a natural person where the person cannot be identified, whether by the data controller or by any other person, taking account of all the means likely reasonably to be used either by the controller or by any other person to identify that individual. ${ }^{*}$ In the context of this article, the term 'anonymity' is used in its broad sense, taking into account the procedural provisions of the courts. Therefore, it includes non-disclosure of the name and the identity, alongside additional measures for the protection of the person's right to privacy, including the possibility of not disclosing a judgement, either fully or in part.

In Estonian administrative court procedure, applying for anonymity is regulated by the following provisions of the Code of Administrative Court Procedure ${ }^{* 10}$ (CACP). Section 175 (3) of the CACP establishes that on the basis of an application by the data subject, or on the court's initiative, the name of the data subject in the judgement to be published is replaced by initials or a sequence of letters, and the subject's personal identification code, date of birth, registration number, address or other particulars that would permit specific identification of the data subject shall not be published. Section 175 (4) and (5) permit publishing a judgement without those particulars whose inclusion entails a risk of harm to the right to privacy or which are subject to other limitation of access provided in the law, publishing solely the operative part of the judgement, or not publishing the judgement, on the basis of an application by the data subject or an interested party or on the court's own initiative.

According to Rule 47 (4) of the Rules of Court as now in force, applicants who do not wish their identity to be disclosed to the public shall so indicate and shall submit a statement of the reasons justifying such a departure from the normal rule of public access to information in proceedings before the ECtHR. The Court may authorise anonymity or grant it of its own motion.

Before the entry into force of the wording now valid for the Rules of Court on 1.1.2014, a similar provision was established by Rule 47 (3) - as the only difference, the party acceding to the application or granting it of its own motion was the President of the Chamber instead of the Court. ${ }^{* 11}$ According to the current wording, the responsibility for finding the balance between the right to privacy and the public interest lies with the entire panel. ${ }^{* 12}$ The author gathers from the above that deciding on the issue of disclosure of personal

6 Article 6 (1) and Article 8 (1). Rome, 4.11.1950.

7 Eesti Vabariigi põhiseadus. - RT 1992, 26, 349 ... RT I 2007, 33, 210 (in Estonian), §§ 24 and 26. English text available at http://www.riigiteataja.ee/en/eli/530102013003/consolide (most recently accessed on 8.8.2015).

8 Rules of Court. European Court of Human Rights; Council of Europe 2014. Available at http://www.echr.coe.int/Documents/ Rules_Court_ENG.pdf (most recently accessed on 8.8.2015).

9 Opinion 4/2007 on the Concept of Personal Data (adopted on 20.6.2007 by the Data Protection Working Party established under Article 29), p. 21. 01248/07/EN, WP136. Available at http://ec.europa.eu/justice/policies/privacy/docs/ wpdocs/2007/wp136_en.pdf (most recently accessed on 8.8.2015).

10 Halduskohtumenetluse seadustik. - RT I, 23.2.2011, 3 ... RT I, 31.12.2014 (in Estonian). English text available at http:// www.riigiteataja.ee/en/eli/509022015001/consolide (most recently accessed on 8.8.2015).

11 Rule 47 (3) and Rule 1 (e). Rules of Court. European Court of Human Rights; Council of Europe 2008. Available at http:// www.echr.coe.int/Documents/Library_2008_RoC_ENG.pdf (most recently accessed on 8.8.2015).

12 Rule 47 (4) and Rule 1 (h). Rules of Court, 2014 (Note 8). 
data is deemed more substantial nowadays, requiring an assessment by all the judges of the Chamber. The article is based on the Rules of Court in their current form and refers to the Court as the applier of anonymity without differentiating between the President of the Chamber and the entire panel as the authority making the decision.

The procedural aspects are specified in the practice direction on requests for anonymity, ${ }^{*} 3$ according to which the ECtHR may take any measure to ensure the inviolability of private life.

\subsection{Informing parties to a proceeding of the possibilities for protecting their right to privacy}

In several documents of the Committee of Ministers of the Council of Europe, ${ }^{*}{ }^{14}$ the Member States are directed to ensure fast dissemination of the ECtHR practice to everyone and in all forms, electronic and on paper. Considering the widespread nature of judicial decisions, both applicants and the court should take the protection of personal data into account before publication of a decision.

The potential applicants are informed of the possibilities for protecting their right to privacy and the obligation to provide argumentation for the request in Rule 47, which has been translated to all languages of the member states of the Council of Europe and establishes the requirements for the content of individual applications. The practice direction on institution of proceedings ${ }^{*}{ }^{15}$ and the practice direction on requests for anonymity ${ }^{*} 6$ thoroughly explain the form and content of submitting the application.

These materials on the possibilities for protecting the right to privacy are publicly available on the website of the ECtHR. Thus, potential applicants can see that the possibility of requesting anonymity exists and read the instructions on its formulation before actually filing an application.

In Estonia, there are no official practice directions on submitting an application to the courts. Instead, the official websites of the courts of first and second instance ${ }^{*}{ }^{* 17}$ contain general descriptions of the requirements for actions under the valid Code of Procedure, by type of procedure, including administrative matters. The possibility of protecting the privacy is not explained in the descriptions of bringing an action found on the websites of the courts, nor in $\S \S 37-39$ of the CACP, which describes the requirements for actions. It is not until $\S 175$ of the CACP that the right of a data subject to apply for non-disclosure of data is addressed, so an average applicant without legal education and a representative will probably not find that provision. Also online, the content of $\S 175$ of the CACP regarding non-disclosure of data in a published judgement is referred to briefly and separately from the requirements related to an action - on the website of the courts of first and second instance, it is in the section for publication of judgements, ${ }^{*} 18$ and on the website of the Supreme Court it is addressed under processing of personal data. ${ }^{*} 19$ Yet there is no description of how to submit the application in question.

Therefore, one can conclude that it is quite difficult for an applicant to find information on applying for anonymity in the context of Estonian administrative court procedure.

Regardless of the above, both courts have concealed the data in publication of approximately six per cent of the decisions. Therefore, the characteristics of informing about the possibility of applying for anonymity cannot be seen to have had a direct impact on these courts' practice in disclosing personal data.

13 Practice direction: Requests for anonymity. President of the European Court of Human Rights 2010. Available at http:// www.echr.coe.int/Documents/PD_anonymity_ENG.pdf (most recently accessed on 8.8.2015).

14 Resolution Res(2002)58 on the publication and dissemination of the case-law of the European Court of Human Rights. Council of Europe, Committee of Ministers, 18.12.2002; Recommendation Rec(2002)13 of the Committee of Ministers to member states on the publication and dissemination in the member states of the text of the European Convention on Human Rights and of the case-law of the European Court of Human Rights. Council of Europe, Committee of Ministers, 18.12.2002.

15 Practice direction: Institution of proceedings. President of the European Court of Human Rights 2013, Section 8. Available at http://www.echr.coe.int/Documents/PD_institution_proceedings_ENG.pdf (most recently accessed on 8.8.2015). The same rule has been established in the earlier wordings since 2003.

16 Practice direction: Requests for anonymity (Note 13).

17 Available at http://www.kohus.ee/ (most recently accessed on 8.8.2015) (primarily in Estonian).

18 Available at http://www.kohus.ee/et/kohtuotsus/haldusasjades (most recently accessed on 8.8.2015) (in Estonian).

19 Available at http://www.nc.ee/?id=1363 (most recently accessed on 8.8.2015) (in Estonian). 


\section{Case law of the European Court of Human Rights and the Administrative Law Chamber of the Supreme Court on disclosure of personal data}

Below, the case law of courts on disclosure of personal data in decisions published in Internet-based databases of judicial decisions is examined. ${ }^{{ }^{20}}$ The period under consideration is 2013-2014, when 1,806 judgements were rendered by the ECtHR and 203 administrative matters settled by the ALCSC. ${ }^{* 21}$ The analysis focuses on determining the fields in which anonymity is ensured for applicants.

The discussion below is organised in terms of the initiative for the issue of anonymity being addressed by the court.

\subsection{Ensuring anonymity by request of a party to a proceeding}

\subsubsection{When all applicants have requested anonymity}

In the period under consideration, the case law of the ALCSC features two cases giving a direct indication that the applicant has requested anonymity from the Court.

In O.S. v. Justiitsministeerium, ${ }^{*} 2$ the applicant filed an application to the Supreme Court to replace his name with initials in the court ruling to be published and not to disclose his personal identification code, date of birth, or address. According to the operative part of the judgement, only the applicant's name was replaced with initials, but actually the personal identification code, date of birth, and address of the applicant were not published in the document either. The case pertained to unjust deprivation of liberty in involuntary admission to care, which is covered by Article 5 of the ECHR. Ensuring anonymity may be related to references to the medical data of the applicant.

The ECtHR acceded to the applications not to disclose the names in analogous cases referring to violation of Article 5 of the ECHR in relation to unfounded detention in a psychiatric hospital ${ }^{* 23}$ or upon assessment of mental health. ${ }^{*}{ }^{24}$ In addition, the ECtHR has acceded to the applications for non-disclosure of names in litigation concerning various medical data, in which violation of Article 8 of the ECHR was found. ${ }^{*} 5$

In the case V. L.v. Maksu-ja Tolliamet, ${ }^{{ }^{2} 26}$ the applicant applied for replacement of name with initials and for non-disclosure of other data that could enable identifying the applicant. According to the operative part, only the applicant's name was replaced with initials, but at the same time, there are no other direct data in the decision as would enable identification. In this case, an application of a taxation official was accepted in relation to removal of the applicant from the official post, repeal of the order to impose a disciplinary penalty, reinstatement in the office, and ordering of compensation. Removal from one's post and disciplinary proceedings could continue to impact a person, due to prejudice, even when the decision is positive for the applicant. An analogous example exists from the earlier case law of the Supreme Court, wherein a reference to termination of a criminal proceeding and unfounded removal from the relevant post in a published decision prevented the applicant from finding a job. ${ }^{{ }^{2} 7}$ There are also cases of an opposite nature in the case law, in which an application to revoke an order to impose disciplinary punishment upon a police officer was satisfied but non-disclosure of data was not requested and the decision was thus published in full. ${ }^{* 28}$ In general, in the Estonian case law, parties to proceedings have sensed the risk of prejudice-related problems in establishment of subsequent (service) relationships in the event of publication

\footnotetext{
Available at http://hudoc.echr.coe.int/ and http://www.nc.ee/?id=11 (most recently accessed on 8.8.2015).

Including administrative matters settled en banc or via the Special Panel.

ALCSCr 22.12.2014, 3-3-1-21-14.

ECtHR 23.9.2014, 67725/10, C.W. v. Switzerland; ECtHR 23.9.2014, 66095/o9, O. G. v. Latvia; etc.

ECtHR 22.10.2013, 11577/06, M. H. v. UK.

ECtHR 23.9.2014, 24453/04, S. B. v. Romania; ECtHR 24.6.2014, 33011/o8, A. K. v. Latvia; etc.

ALCSCd 10.4.2013, 3-3-1-14-13.

SCd en banc 26.3.2012, 3-3-1-15-10, K. M. v. Rïgiprokuratuur.

ALCSCd 15.5.2013, 3-3-1-76-12, Rätsep v. Politsei-ja Pïrivalveamet.
} 
of their personal data in a decision regarding unfounded criminal or disciplinary proceedings, suspension from work, or removal from service.

Analogously, the ECtHR has also acceded to applications for non-disclosure of a name in a hearing addressing a service dispute ${ }^{* 29}$ and in cases involving infringement proceedings against people in relation to unjust criminal proceedings ${ }^{*} 30$ and wrongful arrest. ${ }^{*}{ }^{31}$ Mere publication of the data on the infringement proceedings together with personal data may cause prejudice and stigmatisation of the persons. For instance, in case of a dispute related to deletion of data from the criminal-records database, ${ }^{*} 32$ the objective of the applicants in having recourse to the Court was to clear their names of the earlier charges, which is why the non-disclosure of their names helped to avoid their additional association with being criminally convicted and, hence, the escalation of the violation of their rights.

For a uniform overview of the case law, the ECtHR decisions in which the requests for anonymity have been accepted are examined below; there are no comparable decisions in the Estonian case law. This can be explained by the fact that the case law on Estonian administrative matters is substantially less voluminous.

In the case Sindicatul 'Păstorul cel Bun'v. Romania ${ }^{* 33}$, the ECtHR acceded to the request of the applicants not to disclose their identity. As a rule, upon authorising anonymity, the Court does not disclose the justification of the decision. In this case, non-disclosure of the data of the applicants was explained by way of exception, probably because the respondent country contested the validity of the applicants' anonymity. The ECtHR explained that the purpose of authorising the anonymity of applicants under the Rules of Court 47 (3) is to protect those applicants who find that the disclosure of their data may damage them. Absence of such protection may hinder the free communication of applicants with the court. The case Sindicatul 'Păstorul cel Bun'v. Romania is exceptional also in that the Court did not disclose the identity of the applicants, referring to the intention of the Court to remove all data enabling the identification of the applicants from the court documents. Cases in which the court leaves only the names of the applicants undisclosed are more common in case law. The reason for providing more complete protection in this case probably lies in clear references to strong pressure on the applicants, which forced several of them to withdraw their applications in the course of the proceedings.

The ECtHR has accepted applicant's application for non-disclosure of his or her name in several cases involving the rights of children, in which violation of Article 8 of the $\mathrm{ECHR}^{*} 34$ or some other article ${ }^{*} 35$ by the respondent states was found. At the same time, the ECtHR has accepted an applicant's request not to disclose his or her name in cases related to the rights of children in which no violations of the Convention were found. ${ }^{*}{ }^{6}$ Thus, the need for protection of personal data is in practice often linked to the protection of the family and personal life of the applicant, especially the rights of children, regardless of whether violation of the Convention is found.

Often, the persons applying for non-disclosure of their name are asylum-seekers. This is seen especially often with applications in which it is stated that removal to the country of nationality imposes a risk to the life of the applicants or a risk of persecution and abuse that is in contradiction with Articles 2 and 3 of the ECHR. The ECtHR has acceded to applications for anonymity whether ${ }^{*} 37 \operatorname{or~not~}^{*} 38$ a violation by the State was found. Also, it has been stated in the literature that requesting anonymity is not exceptional when the applicants are afraid of abuse in the event of exile to their country of nationality. In some countries, a failed asylum-seeker may become a victim of persecution upon returning to their home country. Therefore, it is understandable for asylum-seekers who turn to the courts to be afraid that publication of the decision may bring them negative attention from the authorities in their home country. ${ }^{*} 39$

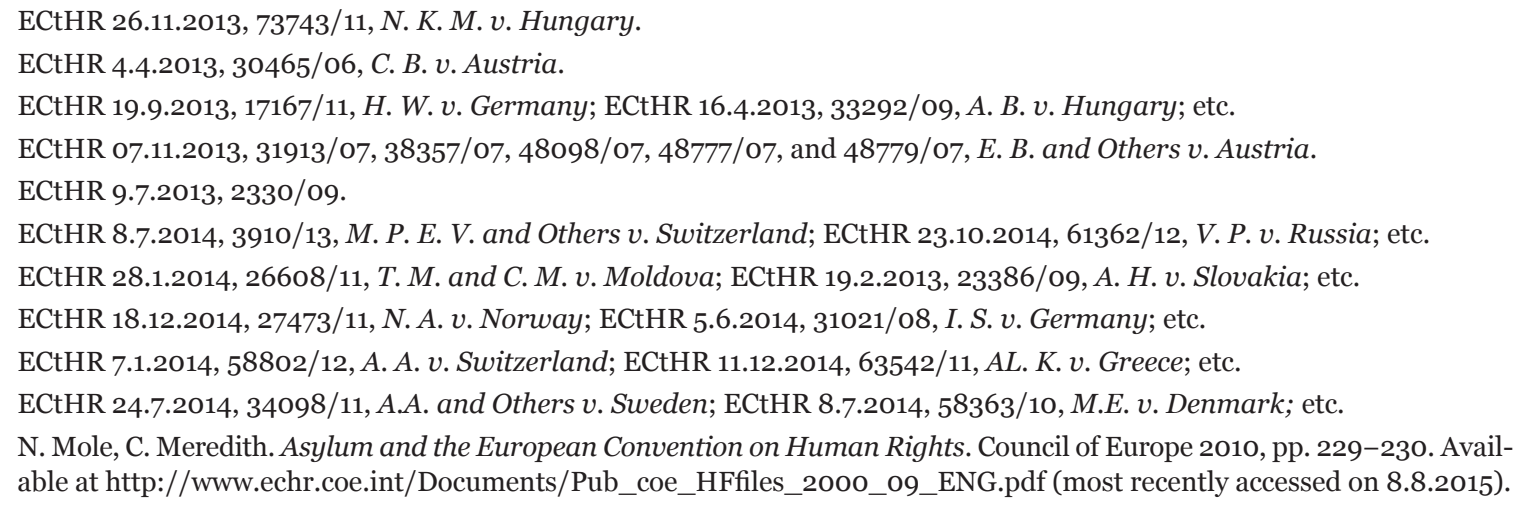


In addition, the ECtHR has accepted an applicant's request for non-disclosure of his or her name in cases involving payment of currency ${ }^{*} 40$ or unfoundedly high taxation of severance payments ${ }^{*}{ }^{4}$. The above refers to the circumstance of the applicants not wishing to associate their names with decisions describing their proprietary situation.

In the cases $W$. v. Slovenia ${ }^{*} 42$ and $N . A . v$. Moldova ${ }^{*} 43$, rape victims contested, respectively, unreasonably long and ineffective criminal proceedings. In both cases, the Court found that Article 3 of the ECHR had been violated and accepted the request of the applicants not to disclose their names. Ensuring privacy can be justified with the need to protect the victim. In an analogous field, a contradictory example could be O'Keeffe $v$. Ireland, ${ }^{*} 44$ regarding sexual abuse of the applicant. Inter alia, violation of Article 3 of the ECHR was found, but the applicant did not request non-disclosure of personal data and the Court did not deem this necessary on its own motion.

In cases of lesser violations in which the ECtHR did not find violations of the Convention, the applicant has submitted and the ECtHR acceded to an application for non-disclosure of the applicant's name where the disputes had to do with degrading treatment by police officers upon detention ${ }^{*} 45$ and the prohibition to wear a full-face veil in public. ${ }^{*} 6$

In the case Söderman $v$. Sweden ${ }^{*} 4$, the circumstances described involved the applicant's stepfather having violated her security of person through attempting to secretly film the 14-year-old applicant naked in the bathroom. At first, the Court acceded to the applicant's application not to disclose her name, and the case was named E.S. v. Sweden. During the proceedings, the applicant changed her mind and the Court acceded to her reverse application by cancelling the anonymity granted.

The above illustrates how much of ensuring the privacy of an applicant is in his or her own hands. The following subsection also accentuates the importance of the subjective understanding of the applicant when one is authorising anonymity.

\subsubsection{When some applicants have requested anonymity}

In the period under consideration, there has been no situation in the case law of the ALCSC in which the Supreme Court acceded to the anonymity application of only some applicants.

The ECtHR joined two applications to form a single proceeding in Z. and Khatuyeva $v$. Russia, ${ }^{*} 4$ acceding to the application of one applicant not to disclose her name while disclosing the name of the other applicant. Regardless of finding violation of Articles 2, 3, 5, and 13 of the ECHR, the Court does not indicate in its decision that the applicants sensed direct threat to their lives or a risk of torture during the proceedings - the fears had to do mainly with a missing relative. At the same time, it cannot be ruled out that persecution by authorities may carry over to those who have dared to file an application to reveal unlawful activities of authorities.

Correspondingly, applications were joined in the case Vallianatos and Others $v$. Greece ${ }^{*} 49$; the names of six applicants were hidden at their request, and the rest of the applicants were named in the decision. In the case of the joined applications, it was found that Article 14 of the ECHR had been violated in conjunction with Article 8. The regulation of partnership of same-sex couples discussed in the case is a delicate topic and disclosure of personal data of same-sex partners could cause additional violation of privacy and discrimination against the applicants.

The above indicates that, upon the initiative of the person, the right to privacy is protected at the highest level. Therefore, the ECtHR has linked the need for substantial data protection with the applicants' own assessment of the potential harm to their rights upon publication of the decision.

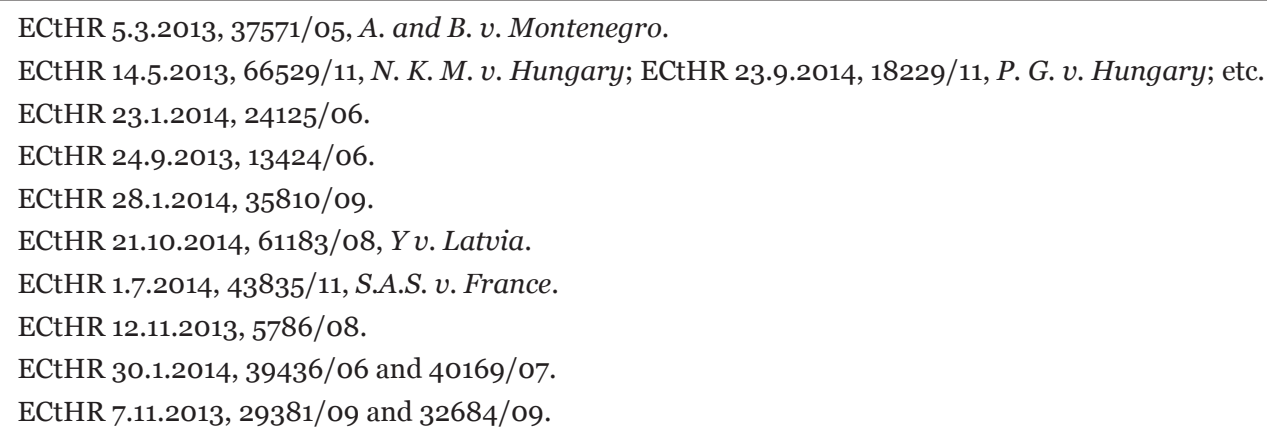


At the same time, disclosure of data on some of the applicants may make it easier to identify another applicant who may wish to conceal his or her identity - for instance, in the Z. and Khatuyeva v. Russia ${ }^{*} 50$ case, wherein the name of the sister of the missing person was hidden but the data on the missing person and her husband disclosed. Therefore, anonymity applications by some applicants should lead the Court to deliberate on the potential consequences of publication of the decision for the other applicants and whether the protection of personal data should be extended to all applicants in the case at issue.

\subsection{Ensuring anonymity on unspecified incentive}

Enabling anonymity on unspecified incentive may take place in consequence of the fact that anonymity is granted for some applicants under a corresponding application and for the rest at the court's initiative. Alternatively, it is possible for the court either not to deem it necessary or to forget to specify whether the issue of non-disclosure of data has arisen on the motion of the applicants or, instead, the court.

The ALCSC has stated in four cases in 2013-2014 that, according to the ALCSC, the names of the applicants (and, in one instance, also a person not participating in the proceedings) shall be replaced by initials upon publication of the decision while not explaining the incentive for this decision.

The Supreme Court replaced the applicants' names with initials in a set of cases involving compensation for damage caused by actions of the Police and Border Guard Board in relation to unlawful detention due to incorrect assessment of the applicant's state of health ${ }^{{ }^{*} 1}$ and involving unlawful compelled attendance, use of means of restraint, and indecent conditions in the place of detention. ${ }^{*}{ }^{2}$ The prisoner's application for compensation for damage caused by the prison was upheld in part since the carelessness of the respondent enabled a fellow prisoner to attack the applicant with scissors. ${ }^{*} 33$ Both the applicant's and the other prisoner's name in the decision were replaced with initials. The applicant's name was replaced by initials also in the decision referring to the psychological and psychiatric problems of the applicant as a prisoner. ${ }^{*}{ }^{5} \mathrm{In}$ general, it can be stated that ensuring anonymity was necessary in these four cases in relation to protection of health records, unlawful deprivation of liberty, and references to criminal or misdemeanour proceedings.

The ALCSC has decided to substitute letters for names in two cases without specifying whether this took place on the motion of the parties to the proceedings or, instead, the court.

The Supreme Court replaced the names of the applicant and the prison doctors with the letters 'A', 'B', and ' $\mathrm{C}$ ' in a case of a prisoner's application to revoke a prison's job assignment order in relation to the applicant's state of health. ${ }^{*} 55$ In a case involving custody of a child, the Supreme Court replaced the names of the applicant (the father), the mother, and the three children with 'A', 'B', 'C', 'D', and 'E' and published the decision without the case numbers referred to in the decision, showing only the years of the referred decisions and of other documents. ${ }^{* 6}$ Although application of anonymity was not justified, it can be concluded from the scope of the defence that the Supreme Court has deemed the protection of health records and one's private and family life, when children are involved, important legal rights that require more effective protection.

Equivalently, several ECtHR decisions state that the Court decided to grant anonymity to applicants but do not specify whether this decision was taken upon the request of the applicants or at the Court's own initiative. Thus, anonymity has been granted to applicants in cases of delayed medical care to a prisoner, ${ }^{*} 57$ deprivation of parental rights and placement of a newborn in a foster home ${ }^{*} 58$, and the incapability of the State to guarantee a parent a meeting with his or her children. ${ }^{*} 59$ Clearly, also in ECtHR practice, nondisclosure of personal data is seen in relation to health records and protection of personal and family life, especially when children are involved.

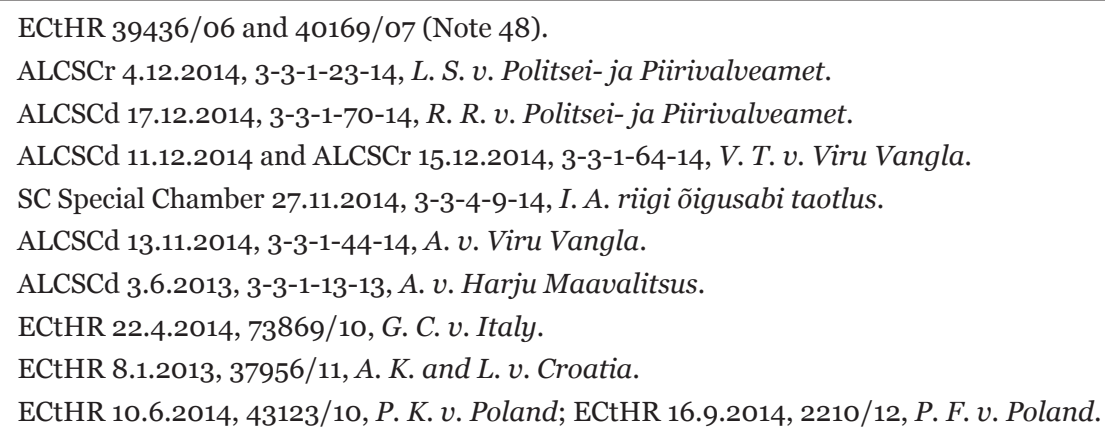


In the period under consideration, the ECtHR has made more than 100 decisions regarding asylum-seekers, often granting them anonymity upon application ${ }^{* 60}$ or without specifying the incentive. ${ }^{* 61}$ At the same time, the Supreme Court has dealt with very few cases involving asylum-seekers and on those rare occasions has not hidden personal data. However, in early 2015, the Supreme Court issued several decisions in which the name of the asylum-seeker is replaced with initials. ${ }^{* 62}$ Therefore, it can be concluded that the Estonian case law with regard to disclosing the data of asylum-seekers is consistent with the case law of the ECtHR.

There are some decisions in both bodies of case law (i.e., that of the Supreme Court and of the ECtHR) in which the applicants' names have been replaced with initials or letters but there is no comment as to the relevant court's decision not to disclose the names.

The Supreme Court has replaced the name of the applicant with an abbreviation that is likely to reference initials in cases related to qualifying an illness as an occupational accident, ${ }^{*} 63$ issuing medications to a prisoner, ${ }^{*}{ }^{*}$ giving a disabled person an assistive device, ${ }^{*} 65$ and damaging the mental health of a prisoner. ${ }^{* 66}$ These four examples are more or less related to the protection of medical data that fall within the scope of Article 8 of the ECHR. In addition, the Supreme Court has replaced the name of the applicant with an abbreviation that probably denotes the initials in the case of a police officer applying for revocation of the order to remove him from service, his reinstatement in employment, and ordering of a compensation, whereat the decision includes references to misdemeanour proceedings against the applicant. ${ }^{*}{ }^{6}$ The latter example is related to the right to choose a profession, and the need for data protection arises from the risk of having difficulties in finding a subsequent job or position, addressed in more detail in subsection 2.1.1.

The ECtHR has left the applicant's name undisclosed without referring to the legal basis in a case in which violation of Article 5 of the ECHR was found in relation to forced placement in a social-welfare institution $^{* 68}$ and in several cases in which, inter alia, violation of Articles 3 and 5 of the ECHR was found in relation to unfounded deprivation of liberty. ${ }^{*} 69$ The ECtHR has also left an applicant's name undisclosed without referring to a decision on maintaining anonymity in cases in which violation of Articles 3 and 8 of the ECHR was found ${ }^{*} 70$ and in cases of violation of Article 8 of the ECHR. ${ }^{*} 71$

The above demonstrates that the courts have often applied anonymity without stating the incentive in cases that involve the applicants' wish to protect the inviolability of private and family life under Article 8 of the ECHR and when there is a real possibility of their right to privacy being violated even further in the absence of anonymity. In addition, the applicants in the cases referred to in this subsection of the paper have often referred to violation of legal values established in Articles 3 and 5 of the ECHR. The courts probably ensured anonymity in these cases because there existed a risk of violation of the same rights in the future.

\subsection{Ensuring anonymity at the court's initiative}

Ensuring anonymity at the court's initiative reflects the most objective consideration of the need for protection of personal data, since the protection takes place upon assessment by an impartial court, not on the basis of the subjective understanding held by the data subject.

Although in $\$ 175$ (3), (4) and (5) of the CACP, an application by the data subject and the court's initiative have both been established as grounds for publishing a judgement without the particulars, there are no

$60 \quad$ See Subsection 2.1.1.

$61 \quad$ ECtHR 18.11.2014, 52589/13, M. A. v. Switzerland; ECtHR 22.4.2014, 6528/11, A. C. and Others v. Spain; etc.

62 ALCSCr 3.2.2015, 3-3-1-56-14, M. A. M. v. Politsei-ja Piirivalveamet; ALCSCr 29.1.2015, 3-3-1-52-14, A. S. v. Politsei-ja Piirivalveamet; etc.

63 ALCSCd 27.11.2014, 3-3-1-66-14, E. R. v. Sotsiaalkindlustusamet.

64 ALCSCr 8.10.2014, 3-3-1-50-14, A. B. v. Tallinna Vangla.

65 ALCSCr 26.5.2014, 3-3-1-22-14, P. K. v. Võru Maavalitsus.

66 ALCSCd 21.4.2014, 3-3-1-17-14, E. T. v. Viru Vangla.

67 ALCSCd 19.6.2013, 3-3-1-22-13, K. L. v. Politsei-ja Piirivalveamet.

68 ECtHR 25.11.2014, 31199/12, K. C. v. Poland.

69 ECtHR 27.11.2014, 46673/10, A. E. v. Greece; ECtHR 21.10.2014, 47146/11, T. and A. v. Turkey; etc.

ECtHR 16.7.2013, 61382/o9, B. v. Moldova; ECtHR 3.10.2013, 552/10, I. B. v. Greece.

ECtHR 17.7.2014, 19315/11, T. v. Czech Republic; ECtHR 25.4.2013, 36337/10, M. S. v. Croatia; etc. 
cases in the case law of the ALCSC with an expressis verbis explanation that the non-disclosure is due to the court's own initiative.

The ECtHR has been active in protecting the data of parties to proceedings on its own motion, as seen in four cases wherein the applicants or other persons concerned were children - in three of them, no identity was disclosed and violation of Article 8 of the ECHR was found, ${ }^{*} 72$ and in the other, anonymity was granted regardless of no violations having been found. ${ }^{*} 73$ Thus, the activeness of the Court in ensuring anonymity is clearly related to protecting the rights of children and ensuring the inviolability of one's private and family life.

Of its own motion, the ECtHR has not disclosed the name of the applicant in three cases in which violation of Article 3 of the ECHR was found, separately or in conjunction with other provisions. ${ }^{*} 74$ Ensuring anonymity was probably necessary to avoid further torturing of the applicants.

Somewhat exceptionally, the ECtHR has ensured anonymity at its own initiative in the case in which violation of Article 10 of the ECHR was found in relation to restriction of the freedom of expression of a journalist. ${ }^{*} 75$

The activity of the ECtHR in protecting personal data has been rather modest. Since there were only eight cases in the period under consideration in which it has been expressed clearly that the applicant's anonymity was ensured at the ECtHR's initiative, no exhaustive conclusions can be drawn. Still, it is more likely for the Court to ensure anonymity of its own motion in cases wherein violations of Article 3 or 8 of the ECHR are found. Since the risk of torture or violation of one's private or family life may continue or even increase in a situation in which a person's data are associated with a respective decision, it is clearly necessary to consider ensuring anonymity to protect the applicant's rights and mitigate the risks.

\section{Conclusions}

Although the provisions regulating anonymity have been set forth differently in the Rules of Court and the CACP, the procedural possibilities given to the courts for applying anonymity are similar between the two. However, informing potential applicants of the possibility of applying for anonymity is different. In the case of the ECtHR, the practice directions on institution of proceedings and applying for anonymity, along with the Rules of Court (Rule 47), inform potential applicants of their right to request anonymity, and the respective application process is explained. In Estonian administrative court procedure, it is rather difficult for an applicant to find information on requesting anonymity.

Although the Estonian case law examined was of smaller volume, the general direction in the protection of the data of parties to the proceedings was still evidently consistent with the case law of the ECtHR with respect to ensuring anonymity. In to the case law, ensuring the privacy of applicants depends largely on the applicants themselves. The courts are quite passive in the protection of personal data, as they have linked the need for substantial data protection mainly with the applicants' own assessment of the potential violation of their rights upon publication of the decision.

Anonymity is more likely to be granted upon an application by the applicant, with unspecified incentive, or on the Court's own motion in cases regarding violations of Articles 2, 3, 5, and 8 of the ECHR. The scope of these articles covers the right to life, prohibition of torture, the right to the integrity of the person, and respect for private and family life. How a request for anonymity is settled does not depend on whether the Court finds a violation by the State in deciding on the merits of the case. However, anonymity is granted at the Court's initiative mainly in the event of finding violation of Article 3 or 8 of the ECHR.

The need to ensure anonymity can be justified, firstly, with ensuring the right to privacy and, secondly, with the risk of escalation of the violations contested in the application if the data of the applicant is associated with the decision.

\footnotetext{
ECtHR 19.2.2013, 1285/o3, B. v. Romania; ECtHR 18.6.2013, 28775/12, R. M. S. v. Spain; ECtHR 26.11.2013, 27853/o9, $X v$. Latvia.

73 ECtHR 29.4.2014, 60092/12, Z. J.v. Lithuania.

74 ECtHR 12.2.2013, 45705/07, D. G. v. Poland; ECtHR 23.7.2013, 41872/10, M. A. v. Cyprus; ECtHR 29.10.2013, 11160/07, D. F. v. Latvia.

75 ECtHR 1.7.2014, 56925/08, A. B. v. Switzerland.
} 